\title{
Novel Palladium(II) and Platinum(II) Complexes with a Fluoropiperazinyl Based Ligand Exhibiting High Cytotoxicity and Anticancer Activity In Vitro
}

\author{
Kayed A. Abu-Safieh,, ${ }^{1}$ Adnan S. Abu-Surrah, ${ }^{2}$ Hani D. Tabba, ${ }^{2}$ Huda A. AlMasri, \\ Randa M. Bawadi, ${ }^{3}$ Fadila M. Boudjelal, ${ }^{3}$ and Lubna H. Tahtamouni ${ }^{4}$ \\ ${ }^{1}$ Department of Chemistry, Hashemite University, P.O. Box 150459, Zarqa 13115, Jordan \\ ${ }^{2}$ Department of Chemistry and Earth Sciences, College of Arts and Sciences, Qatar University, P.O. Box 2713, Doha, Qatar \\ ${ }^{3}$ Department of Physiology and Biochemistry, The University of Jordan, Amman 11942, Jordan \\ ${ }^{4}$ Department of Biology and Biotechnology, Hashemite University, Zarqa 13115, Jordan
}

Correspondence should be addressed to Adnan S. Abu-Surrah; asurrah@qu.edu.qa

Received 10 December 2015; Accepted 31 January 2016

Academic Editor: Josefina Pons

Copyright ( 2016 Kayed A. Abu-Safieh et al. This is an open access article distributed under the Creative Commons Attribution License, which permits unrestricted use, distribution, and reproduction in any medium, provided the original work is properly cited.

cis-Dichloro-palladium(II) and cis-dichloro-platinum(II) complexes $(\mathbf{2}, \mathbf{4})$ of the general formula $\left[\mathrm{M}(\mathrm{N}-\mathrm{N}) \mathrm{Cl} \mathrm{l}_{2}\right](\mathrm{M}=\mathrm{Pd}(\mathrm{II})$ and $\mathrm{Pt}(\mathrm{II}), \mathrm{N}-\mathrm{N}=1$,2-diamino-4-fluoro-5-(4-methyl-1-piperazinyl) benzene, (DFMPB)) and the dicationic palladium(II) complex $\left[\mathrm{Pd}(\mathrm{N}-\mathrm{N})\left(\mathrm{CH}_{3} \mathrm{CN}\right)_{2}\right]\left(\mathrm{BF}_{4}\right)_{2}(3)$ have been prepared and characterized by elemental analysis, ${ }^{1} \mathrm{H}-\mathrm{NMR}-$, mass spectroscopy, and IR spectroscopy. The cytotoxic effect of these complexes against MDA-231 and MCF-7 human breast cancer cell lines and K562 human leukemia cell line has been studied. The influence was dose dependent and varies with cell type. The palladium(II) complex (2) showed superior cytotoxic effect compared with the corresponding platinum(II) complex and the standard, cisplatin, when tested against all the above cell lines.

\section{Introduction}

The similarity between the coordination chemistry of palladium(II) and platinum(II) compounds has led to a large research effort towards $\mathrm{Pd}(\mathrm{II})$ antitumor drugs that are efficient against $\mathrm{Pt}(\mathrm{II})$ resistant therapies and have less side effects [1]. A key factor that might explain why platinum is most useful comes from the ligand-exchange kinetics. The hydrolysis in palladium complexes is too rapid, $10^{5}$ times faster than that of the corresponding platinum analogues [2]. These complexes dissociate readily in solution leading to very reactive species that are unable to reach their pharmacological targets. Accordingly, compared to cisplatin, the corresponding cis-palladium, cis- $\left[\mathrm{Pd}\left(\mathrm{NH}_{3}\right)_{2} \mathrm{Cl}_{2}\right]$, does not show antitumor activity $[3,4]$. Therefore, if an antitumor palladium complex is to be designed, it must be stabilized by a chelate or a strongly coordinating nitrogen ligand [5].

Studies of platinum and palladium compounds with biologically active carriers have yielded promising results in the field of anticancer chemistry and there is potential for varying the biological activity of these complexes by changing the structure of the carrier [6,7]. Significant advances have emerged from this methodology of design [8-10].

Previously, we reported the synthesis and molecular structure of an enantiomerically pure, trans-palladium(II) complex, trans- $\left[\operatorname{Pd}\left\{(\mathrm{R})-(+)\right.\right.$-bornyl-amine $\left.{ }_{2} \mathrm{Cl}_{2}\right]$ that bears the bulky amine ligand $\mathrm{R}-(+)$-bornylamine (endo-(1R)-1,7,7trimethylbicyclo[2-2-1]-heptan-2-amine) [11]. The complex showed similar antitumor activity against HeLa cells when compared with the activity of the standard references, cisplatin, carboplatin, and oxaliplatin. In addition, a palladium complex which contains the bulky nitrogen ligand harmine (7-methoxy-1-methyl-9H-pyrido[3,4-b]indole), trans- $\left[\mathrm{Pd}(\right.$ harmine $\left.)(\mathrm{DMSO}) \mathrm{Cl}_{2}\right]$, exhibited a greater cytotoxic activity against P388, L1210, and K562 cell lines than cisplatin $[12,13]$.

Connors et al. [14] and Meischen et al. [15] have reported different platinum(II) complexes with aromatic amines, such 
as cis-dichloro(4-chloro-1,2-phenylenediamine)platinum(II) and cis-dichloro(1,2-phenylenediamine)platinum(II). Although these complexes were less active than cisplatin, they have showed relevant biological activity against the L1210 leukemic cell lines. de Almeida et al. also reported that platinum(II) complexes with ligands derived from 1,2phenylenediamine have potential cytotoxicity [16]. The evaluated compounds were less active in vitro than cisplatin. Cytotoxic evaluation results suggested that the presence of the strong electron-withdrawing group in the aromatic ring lead to a decrease in the cytotoxicity against human cancer cell lines such as MCF7 and EVSAT (mammary cancers), WiDr (colon cancer), and H226 (lung cancer).

4-Fluoro-5-(4-piperazinyl)-1,2-diaminobenzene has recently been proved to be a valuable intermediate for the synthesis of various benzimidazole derivatives of biological interest, for example, as anticancer agents and bactericides [17]. Furthermore, ferrocenyl-based complexes with 5-fluoro-6-(4-substituted-1-piperazinyl)benzimidazoles have been reported. These complexes were shown to have potency comparable to that of azole-based antifungal agents (miconazole) [18]. It seems that the benzimidazoles with both fluorine and piperazine as substituents lead to a considerable enhancement of the antibacterial potency [19]. The substituted 1piperazinyl derivative belongs to a group of DNA binding fluorochromes used in chromosome staining and some of them exhibit antihistaminic activity [20,21].

It was proposed that a combination between $\mathrm{Pd}(\mathrm{II})$ or Pt(II) and 4-fluoro-5-(4-piperazinyl)-1,2-diaminobenzene could led to the formation of compounds with potent antitumor activity. To our knowledge, as we are aware, no study of palladium(II) and platinum(II) complexes containing 4fluoro-5-(4-piperazinyl)-1,2-diaminobenzene was reported.

As an extension of our studies on both the coordination chemistry of heteroatom containing ligands [22] and the biological activity [23-25] of their metal complexes, we describe here the synthesis and characterization of new square-planar platinum(II) and palladium(II) complexes bearing the bidentate chelate, 1,2-diamino-4-fluoro-5-(4-methyl)-1-piperazinyl benzene (DFMPB). For comparison purposes, the biological activity of the corresponding water soluble, dicationic, diacetonitrile palladium(II) complex was also investigated. The aim of our study was to investigate the influence of DFMPB as a biologically active carrier on the cytotoxic properties of the platinum(II) and palladium(II) complexes against MDA-231 and MCF-7 human breast cancer cell lines and K562 leukemia cell line.

\section{Experimental}

2.1. Materials and Instrumentation. The complex $\left[\mathrm{Pd}\left(\mathrm{CH}_{3} \mathrm{CN}\right)_{4}\right]\left(\mathrm{BF}_{4}\right)_{2}$ was purchased from Aldrich. Reagent grade chemicals were used as received unless otherwise stated. 1,2-Diamino-4-fluoro-5-(4-methyl-1-piperazinyl) benzene was prepared as previously described [26]: (M.p.) $97^{\circ} \mathrm{C}$; IR $\left(\mathrm{KBr}, \mathrm{cm}^{-1}\right): v=3382(\mathrm{mbr}), 3224(\mathrm{~m}), 2943(\mathrm{~m}), 2811(\mathrm{w})$, $1634(\mathrm{~m})$, and $1523(\mathrm{~s}) ;{ }^{1} \mathrm{H}$ NMR (ppm, DMSO- $\left.d_{6}\right): \delta=6.27$ (m, $\mathrm{H}$ arom. $2 \mathrm{H}$ ), 2.78 (br, $\left.\mathrm{CH}_{2} \mathrm{CH}_{2}, 4 \mathrm{H}\right), 2.41\left(\mathrm{br}, \mathrm{CH}_{2} \mathrm{CH}_{2}\right.$, $4 \mathrm{H})$, and 2.19 (s, $\left.\mathrm{CH}_{3}, 3 \mathrm{H}\right)$; MS (EI) (\%): $225\left(\mathrm{M}^{+}, 100\right)$.
Elemental analyses were performed using a EURO EA 3000 instrument. ${ }^{1} \mathrm{H}-\mathrm{NMR}$ spectra were recorded on a Bruker spectrometer operating at $300 \mathrm{MHz}$ using DMSO$d_{6}$ as a solvent with TMS as an internal standard. Infrared spectra ( $\mathrm{KBr}$ discs) were measured on a Nicolet-MagnaIR 560 Spectrophotometer. Mass spectra (EI) were acquired using a Shimadzu-QP5050A. Melting points were measured by a Stuart Scientific melting Apparatus (uncorrected $\pm 0.1^{\circ} \mathrm{C}$ ).

\subsection{Synthesis of Complexes}

2.2.1. cis-Dichloro(1,2-diamino-4-fluoro-5-(4-methyl-1-piperazinyl)benzene)-palladium(II) ([Pd(DFMPB) $\left.\left.\mathrm{Cl}_{2}\right], 2\right)$. A filtered solution of the ligand (1) $(0.065 \mathrm{~g}, 0.29 \mathrm{mmol})$ in acetone $(30 \mathrm{~mL})$ was added to a solution of $\left[\mathrm{Pd}(\mathrm{PhCN})_{2} \mathrm{Cl}_{2}\right]$ $(0.50 \mathrm{~g}, 1.30 \mathrm{mmol})$ in acetone $(50 \mathrm{~mL})$ with continuous stirring. Upon addition, an orange solid was formed. After $5 \mathrm{~h}$ stirring, the precipitate was filtered, washed with acetone $(2 \times 5 \mathrm{~mL})$ and $\mathrm{Et}_{2} \mathrm{O}(2 \times 10 \mathrm{~mL})$, and dried in vacuum.

Yield of $0.41 \mathrm{~g}$ (78\%). M.p. (dec.) $230^{\circ} \mathrm{C}$. Found: C, 33.63; $\mathrm{H}, 4.54 ; \mathrm{N}, 13.75$. Anal. Calc. for $\mathrm{C}_{11} \mathrm{H}_{17} \mathrm{~N}_{4} \mathrm{FPdCl}_{2}: \mathrm{C}, 32.89$; $\mathrm{H}, 4.27$; N, 13.95. IR $\left(\mathrm{KBr}, \mathrm{cm}^{-1}\right): v=3389(\mathrm{mbr}), 3181(\mathrm{~m})$, $3037(\mathrm{~m}), 2725(\mathrm{w}), 1620(\mathrm{w}), 1513$ (s). MS (EI) (\%): $403\left(\mathrm{M}^{+}\right.$, $10), 225\left(\mathrm{M}^{+}-\mathrm{PdCl}_{2}, 45\right)$.

\subsection{2. cis-Diacetonitrile(1,2-diamino-4-fluoro-5-(4-methyl-1-} piperazinyl) benzene) palladium(II) bis(tetraflouroborate) ([Pd(DFMPB) $\left.\left.\left(\mathrm{CH}_{3} \mathrm{CN}\right)_{2}\right]\left(\mathrm{BF}_{4}\right)_{2}\right)$, 3). To a solution of $\left[\mathrm{Pd}\left(\mathrm{CH}_{3} \mathrm{CN}\right)_{4}\right]\left(\mathrm{BF}_{4}\right)_{2} \quad(0.39 \mathrm{~g}, 0.88 \mathrm{mmol})$ in acetonitrile $(3 \mathrm{~mL})$ was added a filtered solution of the ligand (1) $(0.88 \mathrm{mmol})$ in acetonitrile $(4 \mathrm{~mL})$ with continuous stirring at room temperature. Upon addition, a dark orange solution was formed. After $5 \mathrm{~h}$ stirring, the solvent was evaporated to dryness and the isolated product was washed with $\mathrm{Et}_{2} \mathrm{O}(2 \times$ $5 \mathrm{~mL}$ ) and dried in vacuum.

Yield of $0.45 \mathrm{~g}$ (87\%). M.p. (dec.) $210^{\circ} \mathrm{C}$. Found: C, 27.60; $\mathrm{H}, 3.80 ; \mathrm{N}, 12.24$. Anal. Calc. for $\mathrm{C}_{15} \mathrm{H}_{23} \mathrm{~N}_{6} \mathrm{~F}_{9} \mathrm{PdB}_{2} \cdot 4 \mathrm{H}_{2} \mathrm{O}$ : C, 27.36; H, 3.52; N, 12.76. IR $\left(\mathrm{KBr}, \mathrm{cm}^{-1}\right): v=3391(\mathrm{mbr}), 3189$ (m), $3037(\mathrm{~m}), 2715(\mathrm{w}), 1656(\mathrm{~m}), 1509$ (s), $1036\left(\mathrm{ssh}, \mathrm{BF}_{4}\right)$. ${ }^{1} \mathrm{H}$ NMR (ppm, DMSO): $\delta=6.50$ (m, H arom.2H), 3.51 (br, $\left.\mathrm{CH}_{2} \mathrm{CH}_{2}, 4 \mathrm{H}\right), 3.20$ (br, $\left.\mathrm{CH}_{2} \mathrm{CH}_{2}, 4 \mathrm{H}\right), 2.89\left(\mathrm{~s}, \mathrm{NCCH}_{3}, 6 \mathrm{H}\right)$, 2.00 (s. $\left.\mathrm{CH}_{3}, 3 \mathrm{H}\right)$. MS (EI) (\%): $411\left(\mathrm{M}^{+}-\mathrm{B}_{2} \mathrm{~F}_{8}, 12\right), 370\left(\mathrm{M}^{+}-\right.$ $\left.\mathrm{C}_{2} \mathrm{H}_{3} \mathrm{NB}_{2} \mathrm{~F}_{8}, 14\right), 225\left(\mathrm{M}^{+}-\mathrm{C}_{4} \mathrm{H}_{6} \mathrm{~N}_{2} \mathrm{~F}_{8} \mathrm{PdB}_{2}, 100\right)$.

2.2.3. cis-Dichloro(1,2-diamino-4-fluoro-5-(4-methyl-1-piperazinyl) benzene)-platinum(II) ([Pt(DFMPB)Cl $\left.\left.\mathrm{Cl}_{2}\right], 4\right)$. To a solution of $\mathrm{K}_{2}\left[\mathrm{PtCl}_{4}\right](0.42 \mathrm{~g}, 1 \mathrm{mmol})$ in water $(4 \mathrm{~mL})$ was added dropwise the ligand $(1 \mathrm{mmol})$ in methanol $(5 \mathrm{~mL})$ with continuous stirring. After $24 \mathrm{~h}$ in the dark at room temperature, the brown solid formed was filtered, washed with water, and dried.

Yield of $0.36 \mathrm{~g}$ (73\%). M.p. (dec.) $240^{\circ} \mathrm{C}$. Found: C, 24.62; $\mathrm{H}, 3.54 ; \mathrm{N}, 10.92$. Anal. Calc. for $\mathrm{C}_{11} \mathrm{H}_{17} \mathrm{~N}_{4} \mathrm{FPtCl}_{2} \cdot 2 \mathrm{H}_{2} \mathrm{O}$ : C, 25.10; H, 3.26; N, 10.65. IR $\left(\mathrm{KBr}, \mathrm{cm}^{-1}\right): \nu=3449(\mathrm{mbr}), 3051$ (mbr), 2745 (w), 1618 (m), 1516 (s), 1178 (m). MS (EI) (\%): 491 $\left(\mathrm{M}^{+}, 10\right), 321\left(\mathrm{M}^{+}-\mathrm{C}_{5} \mathrm{H}_{11} \mathrm{~N}_{2} \mathrm{Cl}_{2}, 10\right)$. 


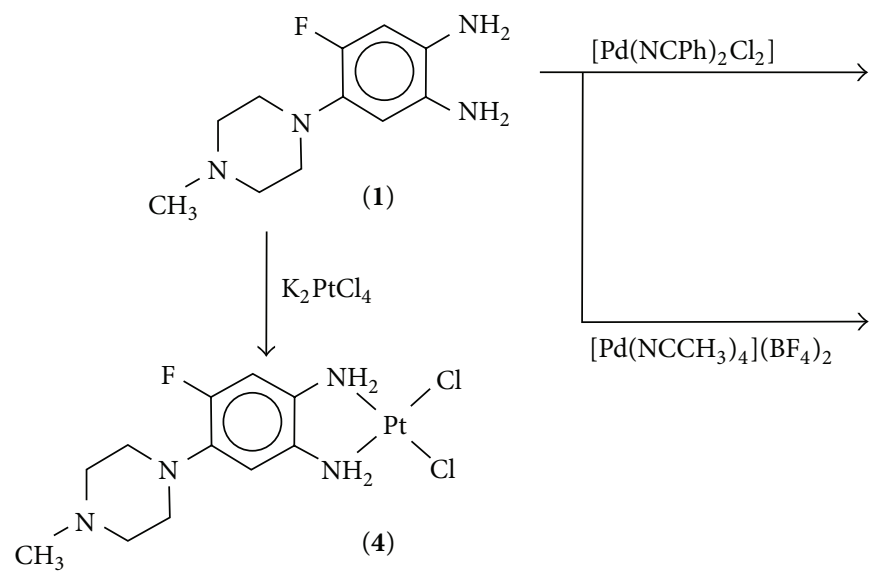<smiles>CN1CCN(c2cc3c(cc2F)N[R](Cl)(Cl)N3)CC1</smiles>

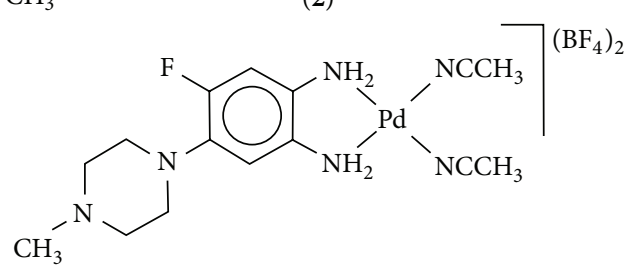

(3)

Scheme 1: Synthesis of the complexes used in the present study (2-4).

\subsection{Biology}

2.3.1. Cell Culture. Human MDA-231 breast cancer cell line was cultured in high glucose DMEM (Gibco, USA) supplemented with $20 \%$ fetal calf serum (FCS) (Euroclone, Italy). Human MCF-7 breast cancer cell line was cultured in RPMI-1640 medium (Euroclone, Italy) supplemented with 10\% FCS. Human K562 chronic myelogenous leukemic cells were cultured in RPMI-1640 supplemented with 10\% FCS. Trypsin-EDTA (Lonza, Switzerland) was routinely used for subcultures. Cell growth was accomplished at $37^{\circ} \mathrm{C}$ in a $5 \%$ carbon dioxide atmosphere.

2.3.2. In Vitro Cytotoxicity (3-(4,5-Dimethylthiazol-2-yl)-2,5diphenyltetrazolium bromide) MTT Test. Cytotoxicity of the various complexes on MDA-231, MCF-7, and K562 cells was evaluated by means of MTT (tetrazolium salt reduction) test $[27,28]$. Briefly, $5 \times 10^{4}$ viable cells were added to each well of a 96-well tissue culture plate containing growth media supplemented with FCS [29]. Cells were kept in a humified $5 \% \mathrm{CO}_{2}$ incubator at $37^{\circ} \mathrm{C}$ for $24 \mathrm{~h}$. The complexes (2-4 and cisplatin) were tested and for each complex six concentrations were prepared in growth media: 0.1, 0.5, 2.5, 5,25 , and $50 \mu \mathrm{g} / \mathrm{mL}$. The complexes were solubilized in $10 \%$ DMSO. The next morning, the different concentrations were added, and the cells were incubated for $24 \mathrm{~h}, 48 \mathrm{~h}$, and $72 \mathrm{~h}$. Freshly prepared MTT salt (3-(4,5-dimethylthiazol-2yl)-2,5-diphenyltetrazolium bromide) $(5 \mathrm{mg} / \mathrm{mL})$ was added to each well to give a final concentration of $0.5 \mu \mathrm{g} / \mu \mathrm{L}$. The plates were incubated for $4 \mathrm{~h}$ and the formation of formazan crystals was checked using an inverted microscope. Equal volume of $1: 1(200 \mu \mathrm{L})$ DMSO and isopropanol mixture was added to each well and incubated for $30-45 \mathrm{~min}$. The inhibition of cell growth induced by the various complexes was detected by measuring the absorbance of each well at $570 \mathrm{~nm}$ using a Statfax microplate reader. For comparison purposes, the cytotoxicity of cisplatin was evaluated under the same experimental conditions.
2.3.3. Clonogenic Assay. $2 \times 10^{5}$ cells were seeded in tissue culture dishes containing growth media supplemented with FCS. Cells were kept in a humified $5 \% \mathrm{CO}_{2}$ incubator at $37^{\circ} \mathrm{C}$ for $24 \mathrm{~h}$. Afterwards, the medium was replaced and the cells were incubated for $3 \mathrm{~h}$ in the presence of an increasing concentration of tested complexes $(0.1,0.5,2.5,5,25$, and $50 \mu \mathrm{g} / \mathrm{mL}$ ). Aliquots of 200 cells were seeded on soft agar for MDA-231 and MCF-7 cell lines and on methyl cellulose for K562 cell line and incubated for 12 days. The colonies were then stained and counted, discarding colonies with less than 50 cells. The surviving fraction (SF) was calculated according to Alverdi et al. [30] and Franken et al. [31].

\section{Results and Discussion}

3.1. Chemistry. The palladium(II) (2) and platinum(II) (4) complexes were prepared by treating each of the starting materials, $\left[\mathrm{Pd}(\mathrm{PhCN})_{2} \mathrm{Cl}_{2}\right]$ and $\mathrm{K}_{2} \mathrm{PtCl}_{4}$, with one equivalent of the diamine ligand, 1,2-diamino-4fluoro-5-(4-methyl-1-piperazinyl) benzene (DFMPB, 1), at room temperature (Scheme 1). The palladium(II) complex, $\left[\mathrm{Pd}(\mathrm{DFMPB})\left(\mathrm{CH}_{3} \mathrm{CN}\right)_{2}\right]$ (3) was prepared by reacting the ligand (1) with $\left[\mathrm{Pd}\left(\mathrm{CH}_{3} \mathrm{CN}\right)_{4}\right]\left(\mathrm{BF}_{4}\right)_{2}$ following our previously published standard procedure [32].

The isolated compounds are microcrystalline or powderlike and stable at atmospheric conditions. The new compounds have been characterized using variety of techniques including elemental analysis, IR-, ${ }^{1} \mathrm{H}-\mathrm{NMR}$-spectroscopy, and mass- (EI-) spectroscopy.

Elemental analyses of the complexes (2-4) showed that the metal to the fluoropiperazinyl ligand ratio in the dichloro complexes is $1: 1$. The presence of the ligands in the complexes was also confirmed by IR-analyses (Table 1). The peaks due to the stretching vibration of the amine $(\mathrm{N}-\mathrm{H})$ showed slight shift to higher frequency. This slight stiffness of vibration refers to complexation of the ligands with the metal (Table 1). Although some of the complexes were microcrystalline, attempts to obtain crystals of suitable quality for an X-ray 
TABLE 1: Analysis of the compounds ${ }^{\mathrm{a}}$.

\begin{tabular}{lcccrr}
\hline Entry & Compound & Compound number & Color & m.p (dec) ${ }^{\circ} \mathrm{C}$ & $\begin{array}{c}\mathrm{IR}^{\mathrm{a}} \\
\mathrm{cm}^{-1}\end{array}$ \\
\hline 1 & DFMPB & $\mathbf{1}$ & Colorless & 97 & $3382,1634,1523$ \\
2 & {$\left[(\mathrm{DFMPB}) \mathrm{PdCl}_{2}\right]$} & $\mathbf{2}$ & Orange & 230 & $3389,1620,1513$ \\
3 & {$\left[\mathrm{Pd}(\mathrm{DFMPB})\left(\mathrm{CH}_{3} \mathrm{CN}_{2}\right]\left(\mathrm{BF}_{4}\right)_{2}\right.$} & $\mathbf{3}$ & Red & 210 & $3391,1656,1509$ \\
4 & {$\left[\mathrm{Pt}(\mathrm{DFMPB}) \mathrm{Cl}_{2}\right]$} & $\mathbf{4}$ & Brown & 240 & $3449,1618,1516$ \\
\hline
\end{tabular}

${ }^{a} \mathrm{~N}-\mathrm{H}$ stretching absorption, $\mathrm{C}=\mathrm{C}$ absorption, and in-plane $\mathrm{NH}_{2}$ scissoring absorption, respectively.

TABLE 2: MTT (3-(4,5-dimethylthiazol-2-yl)-2,5-diphenyltetrazolium bromide) results, the values shown are $\mathrm{IC}_{50}{ }^{\mathrm{a}}$.

\begin{tabular}{|c|c|c|c|c|c|}
\hline Entry & Compound & Compound number & MDA-231 & MCF-7 & K562 \\
\hline \multirow{3}{*}{1} & \multirow{3}{*}{ DFMPB } & \multirow{3}{*}{1} & $(\text { After } 24 \mathrm{~h})^{+}$ & $(\text {After } 24 \mathrm{~h})^{+}$ & $(\text {After } 48 \mathrm{~h})^{+}$ \\
\hline & & & $30.7 \mu \mathrm{g} / \mathrm{mL}$ & $29.2 \mu \mathrm{g} / \mathrm{mL}$ & $25.1 \mu \mathrm{g} / \mathrm{mL}$ \\
\hline & & & $136.27 \mu \mathrm{M}$ & $129.61 \mu \mathrm{M}$ & $110.9 \mu \mathrm{M}$ \\
\hline \multirow{3}{*}{2} & \multirow{3}{*}[\mathrm{Pd}(\mathrm{DFMPB})\mathrm{Cl}_{2}]{} & \multirow{3}{*}{2} & $(\text { After } 24 \mathrm{~h})^{+}$ & $(\text {After } 24 \mathrm{~h})^{+}$ & $(\text {After } 48 \mathrm{~h})^{+}$ \\
\hline & & & $31.1 \mu \mathrm{g} / \mathrm{mL}$ & $28.8 \mu \mathrm{g} / \mathrm{mL}$ & $23.9 \mu \mathrm{g} / \mathrm{mL}$ \\
\hline & & & $63.83 \mu \mathrm{M}$ & $71.53 \mu \mathrm{M}$ & $59.36 \mu \mathrm{M}$ \\
\hline \multirow{3}{*}{3} & \multirow{3}{*}[\mathrm{Pd}(\mathrm{DFMPB})(\mathrm{CH}_{3}\mathrm{CN})_{2}]{$\left(\mathrm{BF}_{4}\right)_{2}$} & \multirow{3}{*}{3} & \multirow{3}{*}{ No effect ${ }^{b}$} & $(\text { After } 72 \mathrm{~h})^{+}$ & $(\text {After } 48 \mathrm{~h})^{+}$ \\
\hline & & & & $50.1 \mu \mathrm{g} / \mathrm{mL}$ & $43.6 \mu \mathrm{g} / \mathrm{mL}$ \\
\hline & & & & $85.29 \mu \mathrm{M}$ & $74.22 \mu \mathrm{M}$ \\
\hline \multirow{3}{*}{4} & \multirow{3}{*}[\mathrm{Pt}(\mathrm{DFMPB})\mathrm{Cl}_{2}]{} & \multirow{3}{*}{4} & $(\text { After } 48 \mathrm{~h})^{+}$ & $(\text {After } 48 \mathrm{~h})^{+}$ & $(\text {After } 48 \mathrm{~h})^{+}$ \\
\hline & & & $42.8 \mu \mathrm{g} / \mathrm{mL}$ & $44.6 \mu \mathrm{g} / \mathrm{mL}$ & $35.4 \mu \mathrm{g} / \mathrm{mL}$ \\
\hline & & & $87.12 \mu \mathrm{M}$ & $90.79 \mu \mathrm{M}$ & $72.1 \mu \mathrm{M}$ \\
\hline \multirow{3}{*}{5} & \multirow{3}{*}{ Cisplatin } & & $(\text { After } 48 \mathrm{~h})^{+}$ & $(\text {After } 24 \mathrm{~h})^{+}$ & $(\text {After } 48 \mathrm{~h})^{+}$ \\
\hline & & & $43.0 \mu \mathrm{g} / \mathrm{mL}$ & $40.1 \mu \mathrm{g} / \mathrm{mL}$ & $25.9 \mu \mathrm{g} / \mathrm{mL}$ \\
\hline & & & $143.31 \mu \mathrm{M}$ & $133.65 \mu \mathrm{M}$ & $86.32 \mu \mathrm{M}$ \\
\hline
\end{tabular}

${ }^{\mathrm{a}}$ The results are shown in terms of $\mathrm{IC}_{50}$ values (the concentration needed to inhibit $50 \%$ of the cellular proliferation). For comparison purposes, the cytotoxicity of cisplatin, a standard antitumor drug was tested under the same conditions.

${ }^{+}$The time it took for the drug to affect cell viability.

${ }^{\mathrm{b}}$ After $72 \mathrm{~h}$ of drug addition, the drug killed at most $15 \%$ of the cells at $50 \mu \mathrm{g} / \mathrm{mL}$.

structure determination were unsuccessful and could be due to the marginal solubility of the dichloride complexes. Therefore, only the solution behavior of complex 3 was determined by NMR spectroscopy in DMSO- $d_{6}$ at room temperature. The ${ }^{1} \mathrm{H}$-NMR experiments showed that the metal to ligand ratio is $1: 1$. It has been indicated that slight shift to higher delta values of the ligand signals is observed upon coordination with palladium.

3.2. Biological Investigations. The cytotoxic activities of the ligand (1) and the corresponding complexes (2-4) were evaluated against human MDA-231 breast cancer cell line, human MCF-7 breast cancer cell line, and human K562 leukemia cell line. The results are shown in Table 2 in terms of $\mathrm{IC}_{50}$ values (the concentration needed to inhibit $50 \%$ of the cellular proliferation). For comparison purposes, the cytotoxicity of cisplatin, a standard antitumor drug, was tested under the same conditions.

The obtained data (Table 2) indicate a superior activity for the palladium(II) complex, $\left[\mathrm{Pd}(\mathrm{DFMPB}) \mathrm{Cl}_{2}\right](2)$, against all cell lines: MDA-231 and MCF-7 breast cancer cell lines and K562 leukemia cell lines $\left(\mathrm{IC}_{50}=63.83,71.53\right.$, and $\left.59.36 \mu \mathrm{M}\right)$ under similar condition. It showed the highest activity among the compounds investigated in the present study. In addition, the organic carrier (ligand, DFMPB, 1) showed substantial activity compared with the standard antitumor drug, cisplatin, and the platinum(II) complex (4) against MDA-231 and MCF-7 human breast cancer cell lines. The noticeable activity of the organic ligand could be due to the presence of the piperazinyl moiety. Previous investigation showed that the presence of a strong electron-withdrawing group in the aromatic ring leads to a decrease in the cytotoxic activity of platinum(II) complexes [16].

However, the platinum(II) complex, $\left[\mathrm{Pt}(\mathrm{DFMPB}) \mathrm{Cl}_{2}\right]$ (4) is more active than cisplatin against only MDA-231 breast cancer and human K562 leukemia cell lines. The corresponding dicationic complex (3) showed higher cytotoxic activity compared with cisplatin and the ligand only against K562 leukemia cell line.

According to Table 2, coordination of the organic biological carrier with palladium significantly increases its biological activity towards all cancer cell lines. However, the corresponding platinum(II) complex showed lower activity than compounds $\mathbf{1}$ and $\mathbf{2}$. This behavior could be due to the relatively lower rate of hydrolysis of the palladium(II) complex caused by the coordination with the ridged aromatic 


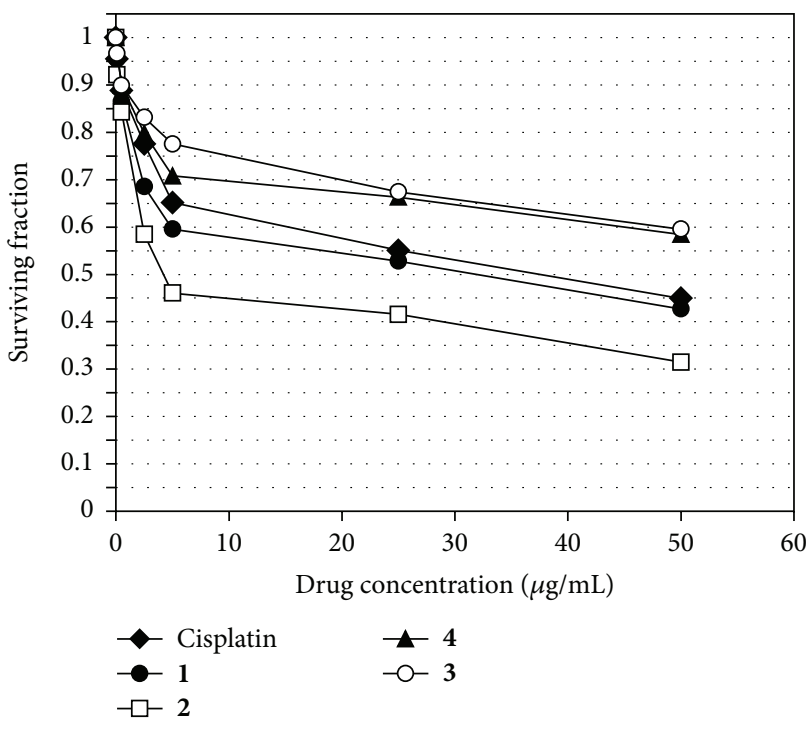

(a)

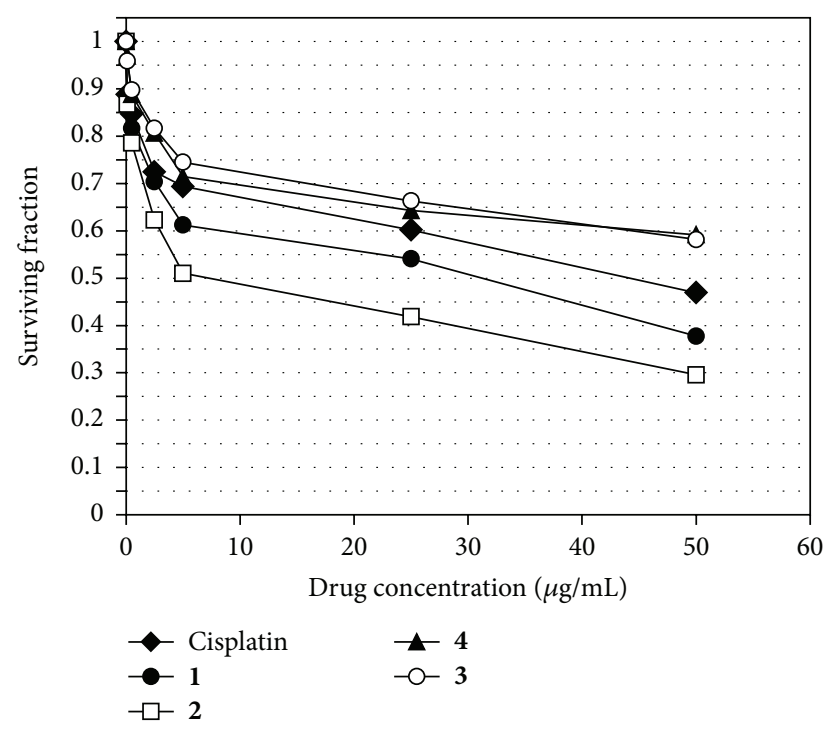

(b)

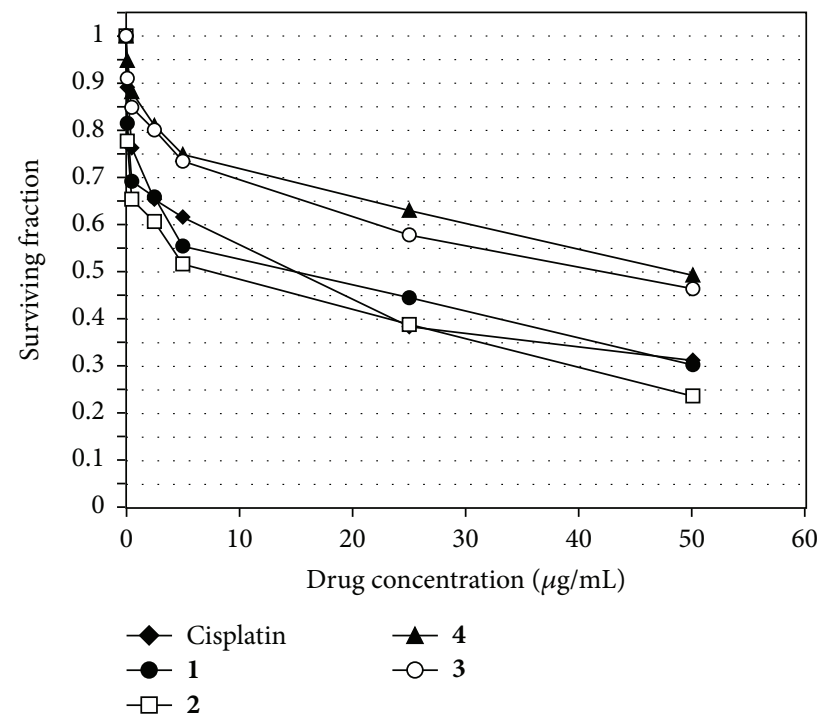

(c)

FIGURE 1: The antiproliferative activity of drugs (2-4 and the standard antitumor drug, cisplatin) was evaluated using the clonogenic assay against (a) human MDA-231 breast cancer cell line, (b) human MCF-7 breast cancer cell line, and (c) human K562 leukemia cell line. The surviving fraction was calculated as number of colonies after treatment/[number of seeded cells $(200$ cells $) \times$ plating efficiency $(\mathrm{PE})]$, where $\mathrm{PE}=$ number of colonies/[number of seeded cells (200 cells) $\times 100 \%]$.

diamine ligand (1). However, due to the relatively lower stability of the dicationic complex (3), the activity towards human MCF-7 breast cancer cell declined.

Based on the cytotoxic activity results above, it seems that both electronic properties and bulkiness of the ligand have a noticeable influence not only on the activity of the palladium(II) but also on its stability. The antiproliferative activity of the new complexes was also evaluated by studying the effect on clonal growth capacity of cells (Figures 1(a)$1(\mathrm{c})$ ). The obtained data suggest that the palladium derivatives show a significant antiproliferative activity similar to that of the reference drug (cisplatin).

\section{Conclusions}

Several strategies have been utilized in order to design a better antitumor drug. Studies of platinum and palladium compounds with biologically active carriers have yielded promising results in the field of anticancer chemistry. In the present study, we showed that the biologically active compound, 1,2diamino-4-fluoro-5-(4-methyl-1-piperazinyl)benzene, could generate palladium(II) and platinum(II) complexes with high cytotoxic activity against MDA-231 and MCF-7 breast cancer cell lines and K562 leukemia cell lines. Our experiments illustrate that the activity against the above cell lines for the 
palladium(II) complex (2) $\left(\mathrm{IC}_{50}=63.83,71.53\right.$, and $59.36 \mu \mathrm{M}$, resp.) is much better than that for the corresponding platinum(II) complex (4) $\left(\mathrm{IC}_{50}=87.12,90.79\right.$, and $72.1 \mu \mathrm{M}$, resp.) and cisplatin $\left(\mathrm{IC}_{50}=143.31,133.65\right.$, and $86.32 \mu \mathrm{M}$, resp. $)$ under similar conditions.

\section{Disclosure}

Current address of Kayed A. Abu-Safieh is Chemistry Department, College of Science, King Khalid University, P.O. Box 9004, Abha, Saudi Arabia. The permanent address of Adnan S. Abu-Surrah is Department of Chemistry, Hashemite University, P. O. Box 150459, Zarqa 13115, Jordan.

\section{Conflict of Interests}

The authors declare that there is no conflict of interests regarding the publication of this paper.

\section{Acknowledgment}

Financial support by the Hashemite University is gratefully acknowledged.

\section{References}

[1] Á. M. Montaña and C. Batalla, "The rational design of anticancer platinum complexes: the importance of the structureactivity relationship," Current Medicinal Chemistry, vol. 16, no. 18, pp. 2235-2260, 2009.

[2] A. S. Abu-Surrah and M. Kettunen, "Platinum group antitumor chemistry: design and development of new anticancer drugs complementary to cisplatin," Current Medicinal Chemistry, vol. 13, no. 11, pp. 1337-1357, 2006.

[3] F. L. Wimmer, S. Wimmer, P. Castan, S. Cros, N. Johnson, and E. Colacio-Rodrigez, "The antitumor activity of some palladium(II) complexes with chelating ligands," Anticancer Research, vol. 9, no. 3, pp. 791-794, 1989.

[4] G. Zhao, H. Lin, Y. Ping et al., "Ethylenediamine-palladium(II) complexes with pyridine and its derivatives: synthesis, molecular structure and initial antitumor studies," Journal of Inorganic Biochemistry, vol. 73, no. 3, pp. 145-149, 1999.

[5] H. Mansuri-Torshizi, T. S. Srivastava, H. K. Parekh, and M. P. Chitnis, "Synthesis, spectroscopic, cytotoxic, and DNA binding studies of binuclear 2,2' -bipyridine-platinum(II) and -palladium (II) complexes of meso- $\alpha, \alpha^{\prime}$-diaminoadipic and meso- $\alpha, \alpha^{\prime}$-diaminosuberic acids," Journal of Inorganic Biochemistry, vol. 45, no. 2, pp. 135-148, 1992.

[6] Y.-P. Ho, K. K. W. To, S. C. F. Au-Yeung, X. Wang, G. Lin, and $\mathrm{X}$. Han, "Potential new antitumor agents from an innovative combination of demethylcantharidin, a modified traditional chinese medicine, with a platinum moiety," Journal of Medicinal Chemistry, vol. 44, no. 13, pp. 2065-2068, 2001.

[7] T. V. Polyanskaya, I. Kazhdan, D. M. Motley, and J. A. Walmsley, "Synthesis, characterization and cytotoxicity studies of palladium(II)-proflavine complexes," Journal of Inorganic Biochemistry, vol. 104, no. 11, pp. 1205-1213, 2010.

[8] F. Z. Wimmer, S. Wimmer, P. Castan, S. Cros, N. Johnson, and E. Colacio-Rodrigez, "The antitumor activity of some
palladium(II) complexes with chelating ligands," Anticancer Research, vol. 9, no. 3, pp. 791-794, 1989.

[9] G. Zhao, H. Lin, P. Yu et al., "Ethylenediamine-palladium(II) complexes with pyridine and its derivatives: synthesis, molecular structure and initial antitumor studies," Journal of Inorganic Biochemistry, vol. 73, no. 3, pp. 745-149, 1999.

[10] A. S. Abu-Surrah, H. H. Al-Sa'doni, and M. Y. Abdalla, "Palladium based chemotherapeutic agents. Routes towards complexes with good antitumor activity," Cancer Therapy, vol. 6, pp. 1-10, 2008.

[11] A. S. Abu-Surrah, T. A. K. Al-Allaf, L. J. Rashan, M. Klinga, and M. Leskelä, "Synthesis, crystal structure and initial biological evaluation of the new enantiomerically pure chiral palladium(II) complex trans-bis\{endo-(1R)-1,7,7-trimethylbicyclo[2.2.1]-heptan-2-amino\} palladium(II)dichloride," European Journal of Medicinal Chemistry, vol. 37, no. 11, pp. 919-922, 2002.

[12] T. A. K. Al-Allaf and L. J. Rashan, "Synthesis and cytotoxic evaluation of the first trans-palladium(II) complex with naturally occurring alkaloid harmine," European Journal of Medicinal Chemistry, vol. 33, no. 10, pp. 817-820, 1998.

[13] T. A. K Al-Allaf, L. J. Rashan, M. T. Ayoub, and M. H. Adday, U.K. Patent No.2 304 712, 1997.

[14] T. A. Connors, M. Jones, W. C. J. Ross, P. D. Braddock, A. R. Khokhar, and M. L. Tobe, "New platinum complexes with antitumour activity," Chemico-Biological Interactions, vol. 5, no. 6, pp. 415-424, 1972.

[15] S. J. Meischen, G. R. Gale, L. M. Lake et al., "Antileukemic properties of organoplatinum complexes," Journal of the National Cancer Institute, vol. 57, no. 4, pp. 841-845, 1976.

[16] M. V. de Almeida, J. D. S. Chaves, A. P. S. Fontes, E. T. César, and M. Gielen, "Synthesis and characterization of platinum(II) complexes from trifluoromethyl phenylenediamine, picoline and $\mathrm{N}$ benzyl ethylenediamine derivatives," Journal of the Brazilian Chemical Society, vol. 17, no. 7, pp. 1266-1273, 2006.

[17] R. J. Abdel-Jalil, R. A. Al-Qawasmeh, W. Voelter, P. Heeg, M. M. El-Abadelah, and S. S. Sabri, "Synthesis and properties of some 2,3-disubstituted 6-fluoro-7-(4-methyl-1piperazinyl)quinoxalines," Journal of Heterocyclic Chemistry, vol. 37, no. 5, pp. 1273-1275, 2000.

[18] R. J. Abdel-Jalil and W. Voelter, "Synthesis of new 2-ferrocenyl5-fluoro-6-(4-substituted-1-piperazinyl)-1H-benzimidazoles of potential biological interest," Journal of Heterocyclic Chemistry, vol. 42, no. 1, pp. 67-71, 2005.

[19] M. P. Wentland, D. M. Bailey, J. B. Cornett, R. A. Dobson, R. G. Powles, and R. B. Wagner, "Novel amino-substituted 3-quinolinecarboxylic acid antibacterial agents: synthesis and structure-activity relationships," Journal of Medicinal Chemistry, vol. 27, no. 9, pp. 1103-1108, 1984.

[20] G. A. Daxhelet, M. M. Coene, P. P. Hoet, and C. G. Cocito, "Spectrofluorometry of dyes with DNAs of different base composition and conformation," Analytical Biochemistry, vol. 179, no. 2, pp. 401-403, 1989.

[21] R. Iemura and H. Ohtaka, "Quantitative structure-activity relationships of H1-antihistaminic benzimidazole derivatives," Chemical and Pharmaceutical Bulletin, vol. 37, no. 4, pp. 967972, 1989.

[22] K. Lappalainen, K. Yliheikkilä, A. S. Abu-Surrah et al., "Iron(II)and cobalt(II) complexes with tridentate bis(imino)pyridine 
nitrogen ligands bearing chiral bulky aliphatic and aromatic substituents: crystal structure of $\left[\mathrm{CoCl}_{2}\{2,6\right.$-bis[R-(+)(bornylimino)methyl]pyridine\}]," Zeitschrift für Anorganische und Allgemeine Chemie, vol. 631, no. 4, pp. 763-768, 2005.

[23] A. S. Abu-Surrah, K. A. Abu Safieh, I. M. Ahmad et al., "New palladium(II) complexes bearing pyrazole-based Schiff base ligands: synthesis, characterization and cytotoxicity," European Journal of Medicinal Chemistry, vol. 45, no. 2, pp. 471-475, 2010.

[24] A. S. Abu-Surrah, T. A. K. Al-Allaf, M. Klinga, and M. Ahlgrend, "Chiral palladium(II) and platinum(II) complexes of diaminocyclohexane: X-ray structures of $(1 R, 2 R)$-(-)-1,2-diaminocyclohexane dihydrochloride and its corresponding oxalato platinum(II) complex," Polyhedron, vol. 22, no. 12, pp. 15291534, 2003.

[25] T. A. K. Al-Allaf, L. J. Rashan, A. S. Abu-Surrah, R. Fawzi, and M. Steiman, "Chemical properties and cytotoxic activity of complexes of platinum(II) and palladium(II) containing dmso and various anions; synthesis and structural characterization of $\left[\mathrm{Pt}(\mathrm{dmso})_{2}\left\{\mathrm{O}_{2}(\mathrm{CO})_{2} \mathrm{CCH}_{2} \mathrm{CH}_{2} \mathrm{CH}_{2}\right\}\right]$," Transition Metal Chemistry, vol. 23, no. 4, pp. 403-406, 1998.

[26] M. M. El-Abadelah, S. S. Sabri, M. H. Abu-Zarga, and R. J. Abdel-Jalil, "Substituted benzimidazoles. Part 1. Synthesis and properties of some 2-aryl-5-fluoro-6-(4-methyl-1-piperazinyl)$1 H$-benzimidazoles," Heterocycles, vol. 41, no. 2, pp. 2713-2728, 1995.

[27] T. Mosmann, "Rapid colorimetric assay for cellular growth and survival: application to proliferation and cytotoxicity assays," Journal of Immunological Methods, vol. 65, no. 1-2, pp. 55-63, 1983.

[28] G. Fotakis and J. A. Timbrell, "In vitro cytotoxicity assays: comparison of LDH, neutral red, MTT and protein assay in hepatoma cell lines following exposure to cadmium chloride," Toxicology Letters, vol. 160, no. 2, pp. 171-177, 2006.

[29] R. Freshney, Culture of Animal Cells: A Manual of Basic Technique and Specialized Applications, John Wiley \& Sons, Hoboken, NJ, USA, 2000.

[30] V. Alverdi, L. Giovagnini, C. Marzano et al., "Characterization studies and cytotoxicity assays of $\mathrm{Pt}(\mathrm{II})$ and $\mathrm{Pd}(\mathrm{II})$ dithiocarbamate complexes by means of FT-IR, NMR spectroscopy and mass spectrometry," Journal of Inorganic Biochemistry, vol. 98, no. 6, pp. 1117-1128, 2004.

[31] N. A. P. Franken, H. M. Rodermond, J. Stap, J. Haveman, and C. van Bree, "Clonogenic assay of cells in vitro," Nature Protocols, vol. 1, no. 5, pp. 2315-2319, 2006.

[32] A. S. Abu-Surrah, G. Eckert, W. Pechhold, W. Wilke, and B. Rieger, "Ultrahigh molecular weight alternating propene/ ethene/carbon monoxide terpolymers with elastic properties," Macromolecular Rapid Communications, vol. 17, no. 8, pp. 559$565,1996$. 

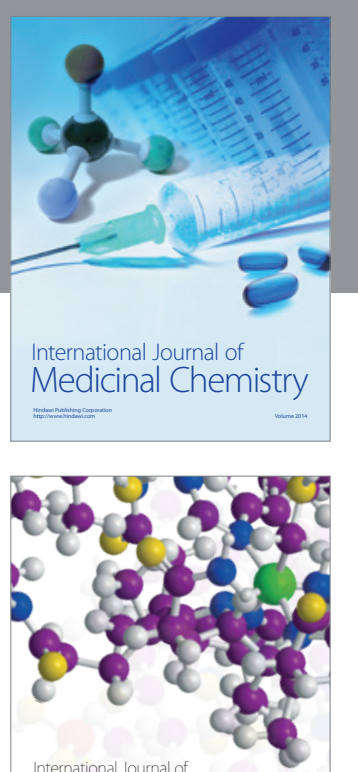

Carbohydrate Chemistry

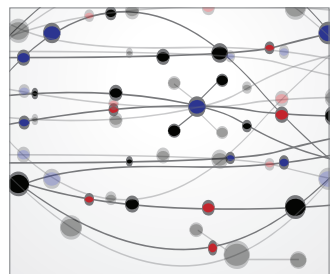

The Scientific World Journal
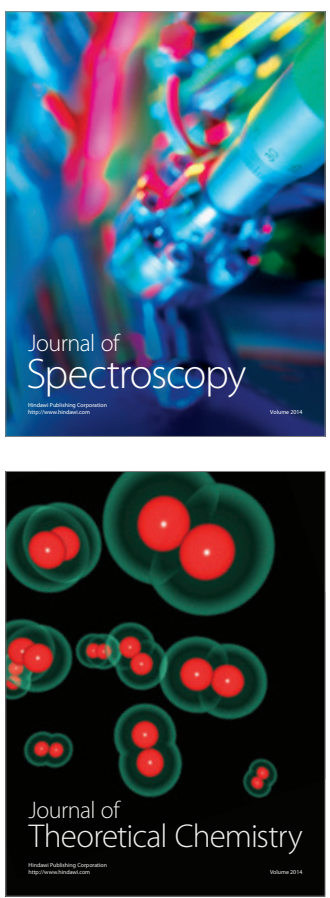
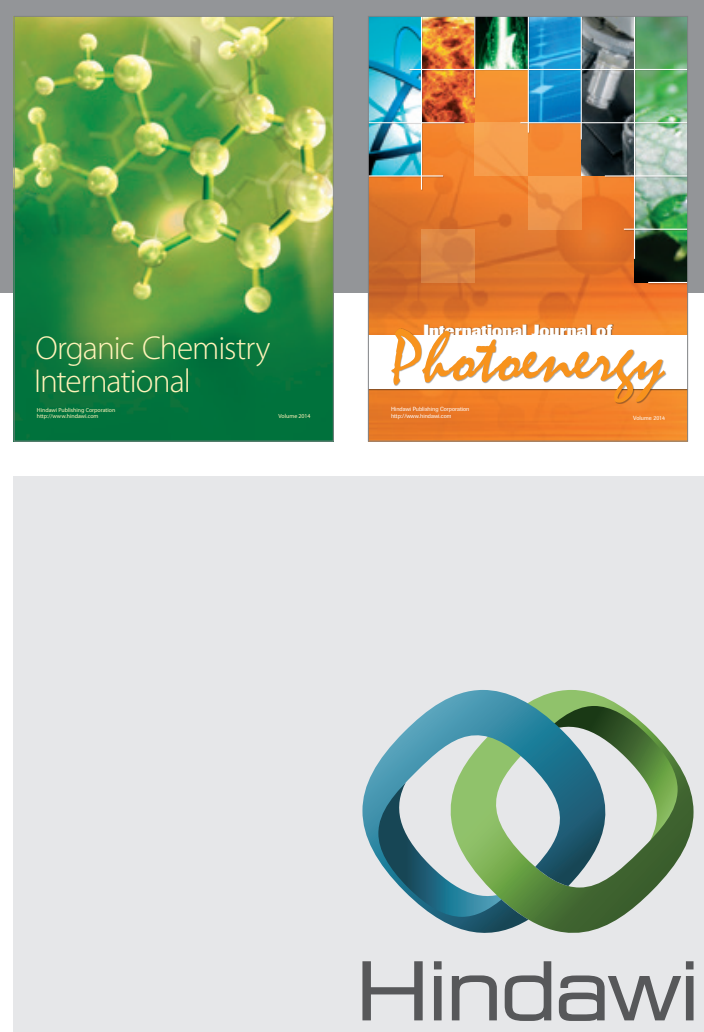

Submit your manuscripts at

http://www.hindawi.com

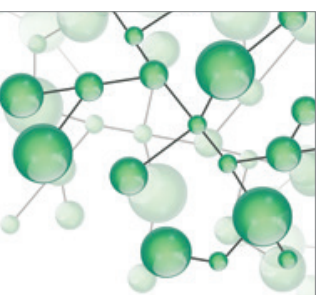

International Journal of

Inorganic Chemistry

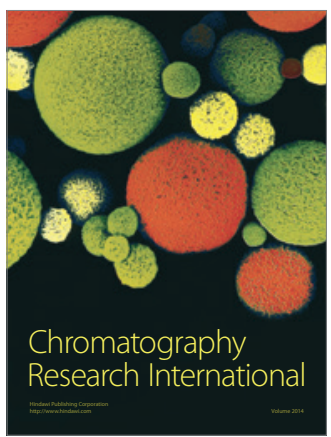

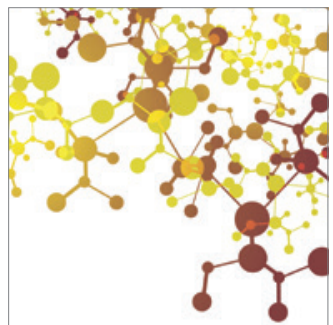

Applied Chemistry
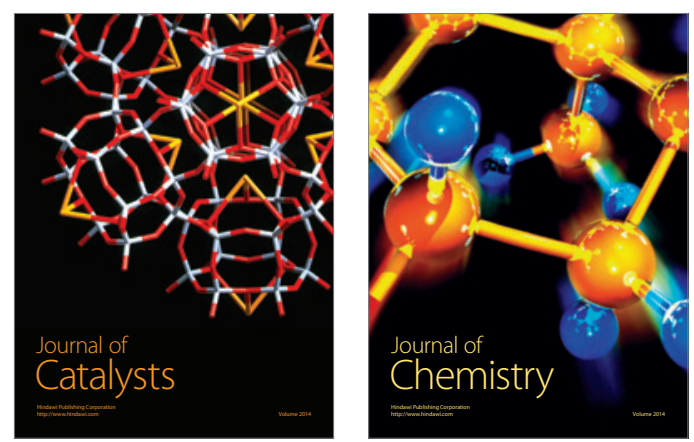
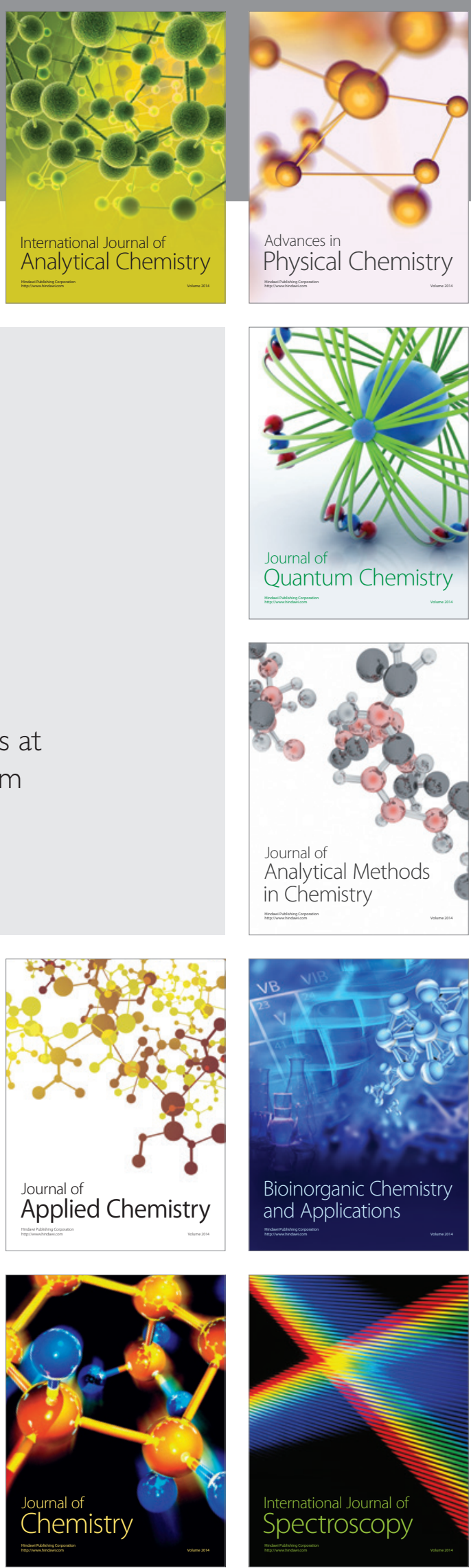